\title{
An Interview with Professor Angus Hikairo Macfarlane
}

\author{
By Alison Kearney
}

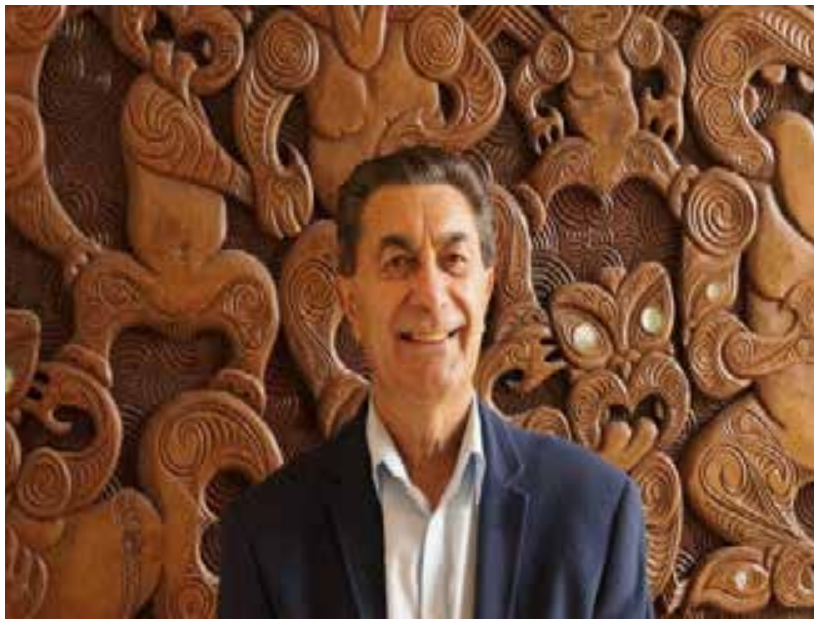

I recently had the privilege of interviewing Professor Angus Macfarlane, Professor of Maori Research at the University of Canterbury. In this interview, Professor Macfarlane shares with readers of Kairaranga his journey as an educator, what he sees as the current issues and successes facing education in Aotearoa/New Zealand, and some wise words of encouragement for all of us involved in the education sector.

\section{Can you tell readers of Kairaranga about your background and your journey as an educator?}

Thank you very much Alison. It is good that you are interacting with me now and we are having this conversation. It is not an easy task for me for while I am often in the foreground of hui, educational discussions, and conference presentations, and have been involved in developing theories and actively contributing to the sector, I am actually a very private person. This is just the way that I prefer things to be. I am not overly fond of dates and years, far better for me to talk in terms of junctures and milestones. I look at this conversation as more to do with selected kāupapa rather than me as an individual, but this might be somewhat difficult, so I will try to attend to both if I can. Allow me to state up front that I am proud to be Ngāti Whakaue and Ngāti Rangiwēwehi - my iwi. I always like to link back to my iwi and waka whenever possible in educational conversations and writings, so I would like to acknowledge my waka, Te Arawa.
I grew up on the eastern shores of Lake Rotorua, the tenth of fourteen children. My Pākehā father was a businessman and my mother a full-time mother. The children pursued various career pathways: one went into medicine, some into business and others into the health sector. I think that I might have been the only one who journeyed into the education realm. My recollection is that we all seemed to do okay at school. Some of us got a lucky break - some sisters went to St Josephs Boarding School for Māori girls and some of the boys, myself included, were sent off to a Māori boarding school in Auckland. In that environment it was instilled in me that a stronger sense of being Māori was normal, and nourishing. All the time it was listening, speaking, singing, praying, acting and interacting, bonding, and even competing, which could well be the reason that from time-to-time I have a competitive edge, or spirit to take things to the limit. I went through the school system very well I think but I didn't go straight into tertiary study. After finishing school I went into the family business - my father and older brother ran a transport business. After a while I knew that there was something else that I wanted to do so I went back to study. I don't think that I was an outstanding undergraduate but I did graduate with a BA. A scholarly experience at Auckland University saw me in the midst of people like Meremere Penfold, Pat Hohepa, Sidney Moko-Mead and Ranginui Walker. They were the icons then as they still are now. Waikato University is where I finished my postgraduate degrees. It was awesome to be in classes taught by Timoti Karetu, John Rangihau and George Marsden, so I had some amazing role models.

It was at postgraduate level that I got more of a feel for things scholastic and then I went into teaching. My last regular teaching job was as a Dean in a reasonably-sized secondary school. It was around that time that I experienced a sea-change. This seachange was when I was appointed head teacher of a special school for adolescents with profound behaviour difficulties. It was not a Maori school, but ninety percent of the roll at the time was Maori. That sea-change got me interested in asking questions related to what makes young people like this who 
they are? What makes them tick? There are no categorical answers or silver bullets of course, but I got to understand that there are socio-psychological ways of understanding these rangatahi, and their behaviours. That took me through to a secondment to Special Education Services and to more tertiary study in the discipline of psychology, then on to the Ministry of Education as a Māori Advisor in the Waikato. While at the Ministry of Education, I was encouraged to apply for a position at the University of Waikato. I was appointed and this was a wonderful opportunity. I think it is Gagne who theorises about the notion of chance - of being in the right place at the right time, and this seemed to have happened for me. But one cannot leave everything to chance. Over time I became an Associate Professor at the University of Waikato teaching in the areas of human development and teacher education. This role provided the opportunity to intensify my learning in the areas of special education and Maori education and to be a part of the pioneering phases of the Resource Teacher: Learning and Behaviour (RTLB) initiative. I am now Professor of Maori Research at the University of Canterbury.

\section{Who has influenced you and your work in education?}

I think that from a young age I may have had a grip on the notion that education was a key instrument and a key door-opener. I think that I may have always had a tendency towards a humanising profession and a qualitative rather than a quantitative direction. The human touch appealed to me then as it does now. The other thing, like many of us, was that I had exemplary teachers. At primary school I have vivid recollections of a teacher, Bill Murray, and at secondary school a Marist Brother, Brother John Paul. They instilled in me a need for motivation, as did my father. He had an influence on me and one of the things he said was "never mind about the transport business, you go and do something else".

But back to the important question that you have posed, Alison. When I think about influence, I prefer to think in terms of mana, given that mana can move people. Here I would go back to the mana of ancestors and the first of these is Makereti, Guide Maggie Papakura. She was a contemporary of that famous duo from the education archives, Vygotsky and Piaget, and she wrote a book called 'Makereti - The Old-Time Māori'. She was a humanitarian, she was a guide, she learnt from her older people and she always checked things out with the iwi, even from England where she studied. Obviously, through her literary legacies, she had the qualities of a good teacher and researcher. She took Maori to the world, another sign that she was a person of mana and influence. So, just to name a few more if I may so as to do justice to your question - I admire the messages from Princess Te Puea of Tainui who said to her people "mahia te mahi - do the work". I often say this to my students, both Māori and non-Māori, to stress the necessity of hard work if they want to succeed. That was a great axiom from a great princess and role-model from the Tainui monarchy. I would also like to mention Rose Pere who reintroduced the concept of ako; Professor Sir Mason Durie - his mana was mana Mātauranga in my view; and Sir Tamati and Lady Tilly Reedy whose mana was mana Māori - the influence of being Māori, of living it and of displaying a disposition that was culturally reasoned. Both were good at that. I also had the privilege of having proximity to Professor Tamati Reedy when he was Pro-Vice Chancellor Māori at the University of Waikato and from time to time I still phone him, seeking guidance. Professor Jim Ritchie was also at Waikato University when I was there and he was a mentor to me when I was studying for my doctorate. His mana was founded on the concept of tangatarua, the ability to walk and work in two worlds. Quite fitting that he would write a textbook entitled 'Becoming Bicultural'. Also, Bev Anaru: Bev has gone now, but she was a great teacher and I didn't get to really know her until I was collecting data on quality teaching practice. I got to shadow her, follow her teaching movements and talk to others about the reasons she was so good. Hers was the mana of the teacher; the mana Whakaako. She features highly in my 2004 book 'Kia hiwa rā! Listen to culture'.

\section{What do you see as the major issue or issues presently facing education in Aotearoa?}

One of these issues I believe is 'capacity' and this has haunted education systems since time immemorial. However, we are getting better and we are addressing the capacity issue, in particular, the numbers of teachers including specialist teachers. If we look at the specialist-teaching programme, for example, we have lost an icon, through retirement, in Jill BevanBrown. She has so much mana and mātauranga - she has left a legacy of thinking and research behind which is fortunate, but who is taking her place and where do we go from here? If we look around, we see scarcity on the ground, so that the need to replenish is very real. This is part of my role and I need to do more work here to try to bridge these gaps.

Another issue, I believe, is the current propensity to measure outcomes which result in comparing schools, ethnicities and abilities, and sometimes this is problematic. Also, a summative approach can be problematic, however, once again I think we are getting better at this. ERO is now looking more 
towards a formative approach which allows us to understand issues and come to terms with factors that present as challenges.

I think that prejudice exists still, in some quarters, largely on account of a lack of awareness of, and appreciation toward, things cultural.

\section{And, as the opposite to the previous question; what good things do you see happening in education in Aotearoa?}

I see so many good things, it is a tonic! One of these is causing me to contradict myself in a way because there is now more of a Maori presence, the numbers who are coming into the specialist teaching programme, the numbers coming into roles such as RTLB, the numbers coming into higher education which is part of my role as Professor of Maori Education. These are now growth areas, meaning there is more of a presence of things Māori. Maori scholarship is more recognised, locally, nationally and internationally. For example, one of the best educational texts ever written is Decolonising Methodologies so that is uplifting.

The Treaty of Waitangi is better understood, at least in the education sector. Educators now understand that the Treaty is not 'a Māori thing'; it is a document that signals that educational advancement is a shared responsibility. It is a shared responsibility and it is for people like you and I, Liz Doell, Mandia Mentis, Sonja Macfarlane and others, to get the messages (about culturally-responsive practices) out to the sector.

Another good thing that is happening in education, in my view, is Ka Hikitia. Unfortunately, it seems that it has been poorly marketed and I think the Ministry understands that, but what a moumou, a waste of an asset, but it is not too late. It has potential.

Another is the change from deficit perspectives to potential perspectives.

\section{(Interviewer) Has that been through Ka Hikitia?}

Yes, but Ka Hikitia is a noun, 'we' is the verb and we can go out there and make sure that culturallyresponsive pedagogies are happening and that Māori children and young people and their whānau are starting to believe more about the new story - one of Māori succeeding in the system. Jim Ritchie's research of fifty years ago was getting the voices of young Māori who were saying then, "I am Māori ... Māori is bad ... I am bad". Compare that to the voices of our recent Rotorua study of high-achieving students: these young Māori were saying "I am Maori ... Maori is tumeke, I am choice". This was a refreshing research programme and, in my view, in tandem with the philosophies of Ka Hikitia, that is, realising Māori potential.

I have always valued the Minister in her role and would like to say that I think the sector is fortunate to have a Minister of Education with such energy and enthusiasm for her role. She recognises good work generally, and advocates for priority learners always. I like her sharp wit and her gall, and of course her proximity to Māoritanga. Following her address at the recent Te Akatea Māori Principals' Conference she joined the kapa haka group on stage for waiata-āringa. Where else in the education world would one see something like that?

\section{What are you working on at the moment?}

There are some really exciting things. First, an edited book with Sonja Macfarlane and Melinda Webber is about to be published. It is entitled Sociocultural Realities: New Horizons in Education and will be launched in November or December of this year. International authors cover the sector from early childhood through to tertiary education. Second, I have just finished writing an article for the New Zealand Journal of Educational Studies (NZJES). It is their $50^{\text {th }}$ year as a leading journal and a few weeks ago the editors contacted me and asked if I would write a piece on looking back on 50 years of Maori education - what an honour and what a job! It was an interesting exercise to retrace the steps from the Hunn Report through to Ka Hikitia, and items of note in between. I have named five seminal programmes over five decades. I can't talk about them here but this article will be coming out in the NZJES later in the year. A couple of research projects are on the go too. One is a National Science Challenge, 'E tipu a Rea - A Better Start'. This is a ten-year plan for the Ministry of Business, Innovation and Employment. The other is a Ministry of Education project, 'Huakina Mai'. This project is an important contributor of the national PB4L initiative, with a focus on 'Getting it Right for Māori'.

\section{What advice would you give to teachers and others involved in education in Aotearoa?}

Keep an open mind; don't rule anything out too readily. Then I would encourage educators to consider a new set of three R's: Reflect, Reassure and Reposition. Be good reflective practitioners: for example, ask yourself "If I had that opportunity again, would I do it the same way? If not, how would I do it differently?" The other R is 'Reassure'. The system has taken enough of a pounding. We need to give ourselves a pat on the back from timeto-time. We provide a good service within which 
are an abundance of exceptional educational practitioners and professionals. We need to reassure ourselves that we are up there with the main players internationally. The final $R$ is 'Reposition'. Education is a dynamic phenomenon, expressed more aptly in te reo as 'Ngā mahi mātauranga o te ao hurihuri'. In order to keep up with the pace it is necessary to reposition our thinking. This might mean going back to the literature, going back to what other people are offering through research and practice, positioning our thinking alongside our own beliefs and, if necessary, repositioning the perceptions and realities we hold dear. Finally, my advice would be 'persevere, never give up', best expressed in the whakatauki: He moana pukepuke e ekengia e te waka: A choppy sea can be navigated.

\section{Is there anything about yourself that you might share with readers of Kairaranga that they might not know about you?}

I grew up in The Beatles era and I love their music, particularly the John Lennon tunes. "Imagine' is a favourite of mine. I used to be a representative tennis player back in the day, and now I kid myself that I can still chase the ball with the same level of energy. There are indoor courts here in Christchurch so I get to play two nights a week and perhaps a Saturday afternoon game - I just love it!

Whānau - my adult children have leadership roles in education and their children, the mokopuna, are the quintessence of life for Sonja and me. Although all brothers and sisters reside in the North Island they are always close to my heart. I go home, on average, once a month, either as part of my work as a researcher, or simply as part of my responsibility toward kin and iwi.

\section{REFERENCES}

Gagne, F. (1992). On the differentiated nature of giftedness and talent, In E. Le Sueur, (Ed.). Proceedings of the Guiding the Gifted Conference, (pp. 19-22). Auckland: Conference Publishing Limited.

Macfarlane, A. H. (2004). Kia hiwa rā! Listen to culture: Māori students' plea to educators. Wellington, NZ: NZCER.

Macfarlane, A.H., Webber, M., Cookson-Cox, C., \& McRae, H. (2014). Ka awatea: An iwi case study of Māori students' success. Report prepared for Nga Pae o te Māramatanga. Christchurch, New Zealand: Te Rū Rangihau, Māori Research Laboratory, College of Education, University of Canterbury.
Makereti (1938). The old-time Māori. London, UK: Victor Gollancz Ltd.

Ritchie, J. (1992). Becoming bicultural. Wellington, NZ: Huia Publications.

Tuhiwai-Smith, L. (1999). Decolonizing methodologies: Research and indigenous peoples. New York: Zed Books and Dunedin: University of Otago Press.

\section{BIO: PROFESSOR ANGUS HIKAIRO MACFARLANE}

Professor Angus Hikairo Macfarlane affiliates to the Te Arawa confederation of tribes in the central North Island. His research and publishing focuses on exploring indigenous and sociocultural realities that influence education and psychology. He has pioneered several theoretical and practical frameworks associated with culturally-responsive and restorative approaches for professionals who are working in these domains. Professor Macfarlane's prolific publication portfolio has earned him national and international standing in his field of scholarship. He has been the recipient of a number of prestigious awards that acknowledge his accomplishments. In 2010 he was presented with the Tohu Pae Tawhiti Award from the New Zealand Council for Educational Research in recognition of his outstanding contribution to Māori research over an extensive period of time. In 2013 he was awarded the University of Canterbury Research Medal - the first ever Māori recipient and the highest honour that the University Council can extend to its academic staff - acknowledging sustained research excellence. In 2015 he received the national Ako Aotearoa Tertiary Teaching Excellence Award. Professor Macfarlane is the Kaihautū (Senior Māori Advisor) of the New Zealand Psychological Society, and Professor of Māori Research at the University of Canterbury, New Zealand. 


\section{INTERVIEWER PROFILE}

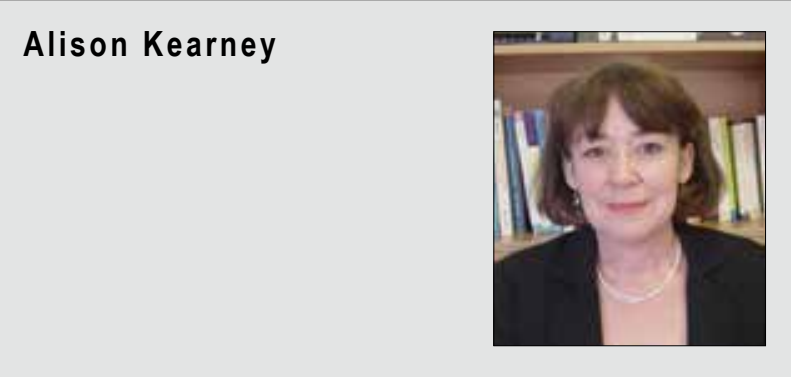

Alison Kearney is an Associate Professor at the Institute of Education at Massey University. Prior to working at Massey, Alison was a primary school teacher, a Resource Teacher of Special Needs, and a Guidance and Learning Teacher. Presently, Alison is the joint national coordinator of the Resource Teacher Learning and Behaviour Training Programme. Her research interests include inclusion and exclusion, learner autonomy and children's rights.

\section{Email:}

a.c.kearney@massey.ac.nz 